\title{
CERBE
}

Center for Relationship Banking and Economics

Working Paper Series

\section{Relational capital in lending relationships: Evidence from European family firms}

Marco Cucculelli

Valentina Peruzzi and

Alberto Zazzaro

\section{Working Paper No. 12}

\section{August 2016}

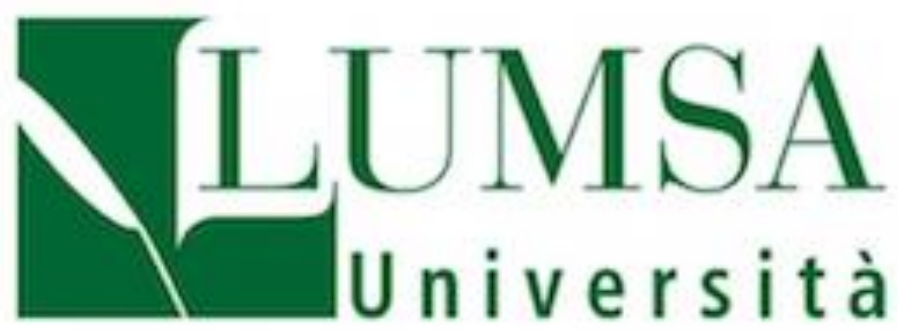

Center for Relationship Banking and Economics Department of Economic and Political Sciences and of Modern Languages LUMSA University Via Pompeo Magno, 22, 00192 Rome - Italy https://sites.google.com/site/cerbelumsa/home

(C) Cucculelli M., Peruzzi V., Zazzaro A. The aim of the series is to diffuse the research conducted by CERBE Fellows. The series accepts external contributions whose topics are related to the research fields of the Center. The views expressed in the articles are those of the authors and cannot be attributed to CERBE 


\title{
Relational capital in lending relationships: Evidence from European family firms*
}

\author{
Marco Cucculelli ${ }^{\S}$ Valentina Peruzzi ${ }^{\dagger} \quad$ Alberto Zazzaro \\ ${ }^{\S}$ Università Politecnica delle Marche and MoFiR, m.cucculelli@univpm.it \\ †Università Politecnica delle Marche and MoFiR, v.peruzzi@ univpm.it \\ †Università di Napoli Federico II, Università Politecnica delle Marche, MoFiR and CSEF, \\ alberto.zazzaro@unina.it
}

\section{December 2016}

\begin{abstract}
In this paper we empirically investigate the effects of active family involvement in the company's management on bank-firm lending relationships and access to credit. Based on the trade-off between relational and management human capital, we explore whether the relational capital embodied in the family leadership of the company influences the lending relationships with the main bank in terms of information sensitivity and duration. Then, we test whether family firms with family CEOs are more likely to experience a credit restriction from banks than family firms appointing professional CEOs external to the family. Results indicate that family businesses appointing family managers are significantly more likely to maintain soft-information-based and longer-lasting lending relationships. However, having family executives does not have a negative impact on firm's access to credit, while the creation of softinformation-based and long-lasting lending relationships significantly reduces the likelihood of experiencing credit restrictions. In view of these findings, family relational capital seems to have a univocal beneficial impact on bank-firm relationship in our sample.
\end{abstract}

Keywords: Family firm, family CEO, soft-information, relational capital, relationship lending, credit rationing.

JEL codes: D22, G21, G22.

\footnotetext{
* We are grateful for comments and suggestions to Stefania Cosci, Rocco Ciciretti, Riccardo Lucchetti, Pierluigi Murro and particpants at the XXIV Conference on Money, Banking and Finance (Rome, Italy), the 3rd CERBE Workshop (Rome, Italy) and seminar helds at the University of Rome Tor Vergata.
} 


\section{Introduction}

A debated issue in the family business literature is the impact of active family involvement in the company's management on firm performance. Two major theoretical trade-offs are typically distinguished to determine advantages and disadvantages of family management and explain the mixed empirical findings: the agency trade-off (Villalonga and Amit, 2006), and the stewardship trade-off (Miller et al., 2011, 2013). According to the agency trade-off, family appointed executives may lower the negative impact of information asymmetries between ownership and management, at the cost, however, of exacerbating the risks of diversion of resources out of the company. In the stewardship trade-off, long-term family CEOs may support the prosperity of the company in the long run by investing resources in nurturing its reputation and social ties, at the cost of promoting nepotism.

A third potential trade-off associated with the family's involvement in the business is the relational human capital trade-off between managerial skills and relational resources, recently explored in the literature (Chung and Luo, 2013; Bennedsen and Fan 2014; Bennedsen et al., 2015; Carillo et al., 2015). In this case, the trade-off underlying the choice of who was to be entrusted with the leadership of the family business grounds on three key considerations. First, both the management human capital of the business leader and the web of relationships of the family built over time by the founder and other family members are important factors in the running of a firm successfully. ${ }^{1}$ Second, family reputation and relationships are intangible assets that cannot be easily passed on to professional managers outside the family circle. Third, the management human capital available within the limited circle of family members tends to be, on average, lower than what can be secured by entrusting the firm's leadership to unrelated managers (Bloom and Van Reenen, 2010; Caselli and Gennaioli, 2013; Carillo et al., 2015). In this scenario, hiring an external CEO selected from a large pool of professionally qualified candidates allows to enhance the quality of management of the company, but this will happen at the expense of the relational capital of the firm. In contrast, entrusting the leadership to a family

\footnotetext{
1 As observed by a third-generation CEO of a successful Italian family company interviewed by the business historian Andrea Colli (2012, p. 253), "the most important thing my father passed on to me was not the company in itself, nor its financial good shape, nor the money and capital, nor even the business idea [...]. The most important thing he gave us was the reputation of the company, and with the reputation, contacts and personal relationships."
} 
member allows to rely on a unique set of valuable assets, like family names and values, tacit knowledge and personal connections, that permit better and easier access to internal and external resources, at the cost, however, of being constrained by a lower management human capital (Le Breton and Miller, 2005; Bennedsen and Fan, 2014; Luo et al., 2014; Carillo et al., 2015).

Unlike agency and stewardship trade-offs, the trade-off between relational and human capital trade-off can be of crucial importance for relationships with subjects outside the company (customers, suppliers, lenders), and access to external resources. In this paper, we examine the role of family firm management in the context of bank relationships. First, we investigate whether the relational capital embodied in the family leadership of the company influences the lending relationships with the bank in terms of information sensitivity and duration. Specifically, we test whether the bank relationships of family owned companies with a family appointed CEO are more strongly dependent on the exchange of private soft information than those held by family firms and directed by a professional CEO, and whether these relationships are longer lasting. Second, we test whether banks value the leadership of professionals and their management human capital in decisions relating to lending. Specifically, we test whether family firms managed by professional CEOs are less likely to experience a credit restriction than family firms with a family management, once the availability of information and the length of the lending relationship are controlled for.

In our empirical analysis, we draw information about a firm's ownership, management leadership and bank relationships from the EU-EFIGE/Bruegel UniCredit survey (Altomonte and Aquilante 2012). This survey covers a large sample of manufacturing firms in seven European countries, and provides detailed data on the type and importance of information required by banks for assessing the creditworthiness of a firm, the duration of the lending relationship with the main bank, the firm's credit demand and its access to loans.

By way of preview, we find that family owned businesses run by family CEOs are significantly more likely to create soft-information-based and long-lasting lending relationships than in the case of family firms hiring external CEOs, a result which is consistent with the idea that relational capital matters in shaping bank-firm relationships. These findings are robust to a different definition of soft-information-based lending ties and long-lasting lending relationships. 
In contrast, the management human capital of non-family professional executives has no significant impact on access to bank credit, while the creation of soft-information-based lending relationships significantly reduces the likelihood of firms experiencing a credit restriction. On the whole, therefore, our results suggest that the family relational capital of CEOs appointed within the family circle plays a significant and beneficial role in bank relationships, which is not offset by adverse effects on access to credit due to (potentially) inferior management skills.

The remainder of the paper is organised as follows. In Section 2, we review the related literature on a family firm's relational capital and access to credit, and formulate our testable hypotheses. In Section 3, we describe the dataset and the variables employed in the regression analyses. Section 4 presents the econometric models used to test our hypotheses. In Section 5, we discuss our empirical results, and Section 6 concludes the paper.

\section{Related literature and testable hypotheses}

\subsection{Related literature}

Our research is primarily related to three strands of the family business and banking literature. Before developing our testable hypotheses, we first shortly introduce the literature on the impact of family management on firms' performance and the role of the family relational capital. Then, we discuss the literature on family firms' access to bank credit. Finally, we briefly summarize the literature on information in lending relationships, and the role of soft information and longlasting relationships with the bank on credit availability to firms.

\subsubsection{Family firms' relational capital}

The crucial role of a family firm's relational capital in the pursuit of a business enterprise has been well documented in the academic literature. Historical research reports many examples of successful business and industry ventures based on family relationships, in some cases promoted or cemented by arranged marriages, parenthood and affiliation to societies (Rose, 2000; Alfani and Gourdon, 2012; Braggion, 2011; Colli, 2012). Consistently, management and economic studies indicate that family companies invest large amounts of resources in nurturing 
interpersonal relations, and building webs of business and political contacts, and that family relational capital has an influence on leadership succession and performance.

Salvato and Melin (2008), for example, analyse the case of four family businesses in the wine industry, and show that their ability to create financial value over many generations does not result from possession of any unique resources, but from their dedicated efforts in renewing and reshaping social interactions. Other studies find that, in order to capture public resources, avoid expropriations, and improve their economic performance, family firms are more likely to develop political connections, both in emerging markets and developed Western countries (Faccio and Parsley, 2009; Amore and Bennedsen, 2013). For a sample of Thai companies, Bunkanwanicha et al. (2013) show that publicly traded stock of family firms experienced positive abnormal returns when a family member married a person from a prominent family with a political background. Similarly, politically connected founders in China are documented to be more likely to appoint a second-generation family member as CEO or board member (Xu et al., 2015). Finally, consistent with the hypothesis of family firms that trade human capital for relational capital in business succession, Bloom and van Reenen (2007) find that the quality of management of second-generation family owned enterprises with a family CEO is lower only if the succession is determined by primogeniture. In the same vein, Carillo et al. (2015) find that the worst management quality of family managed firms is broadly limited to societies characterised by strong family values. Finally, Chung and Luo (2013), considering a large sample of Taiwanese listed companies, show that the profitability premium of appointing professional and talented CEOs external to the controlling family is mitigated, and even reversed, in firms for which the relational capital is arguably of greater importance.

\subsubsection{Relational capital and lending relationships}

Despite lending by banks being the major source of external financing for the greatest part of family businesses, the impact of firms' leadership on bank-firm relationships is still a relatively unexplored issue. The finance literature has investigated the harshness of financing constraints for family firms, indicating that publicly traded family companies are significantly associated with lower investment cash flow sensitivity and lower cost of debt financing (Anderson et al., 
2003; Andres, 2011; Pindado et al., 2011). Similarly, the banking literature has highlighted a beneficial effect of family ownership on the availability of credit, both in normal times and during the recent financial crisis, although the impact on loan contract terms seems to be mixed.

Bopaiah (1998) analyses the availability and cost of credit to a large sample of US smallmedium enterprises included in the National Survey of Small Business Finance (NSSBF). Following Petersen and Rajan (1994), she looks at the percentage of discounts offered to firms using trade credit as a proxy for restrictions in access to bank credit, and finds that discounts offered to family owned enterprises are significantly larger than what are offered to non-family firms. However, Bopaiah (1998) also finds that family ownership does not have any statistically significant effect on rate premiums paid on the loans, while Steijvers et al. (2010), using the same survey, show that family owned enterprises are more likely to pledge collateral in lending. Similar evidence is provided by Cucculelli and Peruzzi (2016), who show that founder-run family businesses are associated with deeper screening technologies than non-family owned companies in their access to credit.

The importance of family relational capital in bank lending relationships has been recently analysed by D'Aurizio et al. (2015) and Stacchini and Degasperi (2015) who look, respectively, at access to credit and interest rate in Italian family firms. The former documents that after the Lehman Brothers' collapse, credit availability to family firms shrank significantly less than the amount of credit to non-family firms. What is more interesting, D'Aurizio et al. (2015) show that the average positive effect of a family firm ownership on credit availability is almost entirely driven by banks that increased the use of soft information during the crisis, thus suggesting that family relational capital played a crucial role in limiting loan contraction in the quarters after Lehman's failure. Stacchini and Degasperi (2015) consider a sample of Italian manufacturing firms included in the EFIGE survey, and find that family ownership is associated with a significant interest discount (15 basis points), and that this discount is especially large (even 80 basis points) for bank-firm relationships in regions where social capital and trustiness is low, thus indicating that family relational capital is a substitute for the lack of general trust in society.

However, these studies ignore the effects that the family's involvement in the company's management has on bank relationships and access to credit. The only exception is Bopaiah (1998) 
who distinguishes the owner-managed firms finding no significant association with the percentage of discounts taken by the firm and, hence, with bank credit restrictions.

\subsubsection{Determinants and effects of soft information production}

A well-established result in banking literature is that the production of soft information about borrowers plays a fundamental role in lending relationships. Traditionally, the availability of soft information is subsumed in the duration, exclusivity, or multiplexity of the lending relationship (Petersen and Rajan 1994, 1995). Recently, however, a growing number of studies have specifically explored the production of soft information by using data from surveys on borrowers/lenders, or from the bank's credit files. Uzzi and Lancaster (2003), using information from interviews with loan officers of 11 banks in the Chicago area, show that social closeness to, and familiarity with borrowers is a primary source for lenders of subjective private information and new knowledge. Based on a questionnaire survey conducted on loan officers of an Italian regional bank, Chelli and Zazzaro (2008) find that the probability of loan officers funding a business start-up is positively associated with the importance that they give to soft information.

Closest to our paper, a number of studies have analysed the determinants of the importance of soft information availability in lending relationships on the basis of a firm's self-reported responses to questionnaires. Scott (2004) analyses a large sample of US small and medium enterprises required to indicate the importance of a number of characteristics related to soft information production in conducting business with their banks (personal knowledge, experience with the firm's industry, integration with the local community). Consistent with the hypothesis that large banks are at a disadvantage in producing soft information (Stein, 2002), he finds that production of soft information is significantly higher for firms borrowing from small community financial institutions, and when loan officers responsible for the relationships are not rotated over time, while it loses its importance for firms that have experienced a recent loan rejection. Uchida et al. (2012) use information from a survey on a sample of small and medium enterprises in Japan. They find that the banks' extent of knowledge of business, industry and markets of their borrowers is negatively impacted by rotation of loan officers at branches, and a lack of one-toone assignment of specific loan officers to specific firms, while it is positively associated with 
face-to-face contacts especially if conducted at the firm's headquarters. Using the same survey, Uchida (2014) also finds that small regional banks are perceived by their borrowers to put greater emphasis on soft information, while Ogura and Uchida (2014) report similar results for small banks experiencing a consolidation or an increment in their organisational complexity. Bartoli et al. (2013), using survey data on Italian manufacturing firms, document that the likelihood of a firm considering production and acquisition of soft information as the main factor driving the selection of their main bank is significantly associated with the importance that the same bank attributes to soft information in granting loans.

Finally, a number of studies have documented that availability of soft information improves a firm's access to credit and increases a firm's investments (Liberti and Mian, 2009; Uchida et al., 2012; Ferri and Murro, 2015). In particular, Cosci et al. (2015), using the EFIGE survey, show that firms that are routinely involved in interviews with loan officers on the firm's policies and prospects, and report business plans and targets to the banks, are less likely to suffer credit rationing, and are more likely to innovate.

We improve upon this literature by investigating whether a firm's corporate governance, and in particular family ownership and family management, affects the production of soft information.

\subsection{Testable hypotheses}

Starting from this literature, in this paper we test two new hypotheses related to the relational human capital trade-off in family businesses. We focus, in detail, on whether the involvement of family members in the management of the family firm have a positive impact on production of soft information, at the cost of a lower access to credit due to the lower average management human capital. Specifically, we test the following two hypotheses.

Hypothesis 1. If family relational capital matters in lending relationships, family owned firms with a family CEO are more likely to maintain soft-information-based and longer-lasting lending relationships with their main bank. 
Hypothesis 2.To the extent that, on average, family members are characterised by a lower management human capital than non-family professional managers, family firms managed by family CEOs are more likely to experience a credit restriction, once controlled for the effects of relational capital on the production of soft information and the use of relationship-lending technology.

\section{Data sources and variable definitions}

\subsection{Datasets}

We draw information from two sources: (1) the EU-EFIGE Bruegel-UniCredit survey on "European Firms in a Global Economy"; (2) the BvD-Amadeus database. The EFIGE survey collects information about a firm's ownership, its governance, financial condition and lending relationships for a representative sample (at the country and industry level) of almost 15,000 manufacturing firms in seven European countries: Austria, France, Germany, Hungary, Italy, Spain and the UK. ${ }^{2}$ The survey was conducted in early 2010 , and information is mostly collected as a cross-section for the year 2008, although some questions cover the period 2007-2009. Then, we merged EFIGE survey data with balance sheets of surveyed firms, as provided by BvDAmadeus, the most comprehensive and widely used source of financial information for public and private enterprises in Europe.

\subsection{Variable definitions}

In Table 1, we report the complete list of the dependent and independent variables used in the empirical analysis, their definitions and descriptive statistics. Here we provide a detailed description of their measurement.

\subsubsection{Family ownership and control}

Despite the widespread literature on family businesses, there is no clear consensus on how family firms should be defined. Theoretical and empirical studies have proposed definitions based on ownership shares, family involvement in the business, and some combinations of the two criteria

\footnotetext{
${ }^{2}$ In the empirical estimation, the number of German firms has been drastically reduced because of several missing information about question F16.
} 
(La Porta et al., 1999; Faccio and Lang, 2002; Anderson and Reeb, 2003; Barontini and Caprio, 2006; Villalonga and Amit, 2006). In this study, we distinguish between family owned and managed businesses on the basis of self-reported information in the questionnaire. In particular, based on questions A20 and A21 of the EFIGE survey, ${ }^{3}$ we classify (1) as family owned firms, those companies directly or indirectly controlled by an individual or a family owned entity (FAM_FIRM), and (2) as family managed firms, those companies that are run by the individual who owns or controls the firm, or by a member of the controlling family (FAM_CEO). As reported in Table 1, more than $70 \%$ of the whole sample is comprised of family owned enterprises, and $88 \%$ of such firms promote family members as CEOs (Table 2).

\subsubsection{Information and lending relationships}

Banks routinely collect hard and soft information on borrowers' business and creditworthiness during a lending relationship. Hard information consists of quantitative data that can be verified and easily communicated, for instance, balance sheet data. Soft information consists of subjective knowledge acquired by lenders in the course of repeated face-to-face interactions with borrowers. Lending relationships make use of these types of information to a different degree.

In the EFIGE survey, firms are required to indicate the type of information that they normally provide to their main bank in the screening and monitoring process. Specifically, question F16 reads as follows:

F16. Which type of information does the bank normally use/ask to assess your firm's creditworthiness? (a) collateral (yes/no); (b) balance sheet information (yes/no); (c) interviews with management on firm's policy and prospects (yes/no); (d) business plan and firms' targets (yes/no); (e) historical records of payments and debt service (yes/no); (f) brand recognition (yes/no); $(g)$ other (yes/no).

\footnotetext{
${ }^{3}$ Questions 20 and 21 read as follows: A20. Is your firm directly or indirectly controlled by an individual or a family-owned entity? (yes/no). A21. Is the CEO of your firm (i) the individual who owns or controls the firm or a member of the family that owns/controls it? (ii) a manager recruited from outside the firm? (iii) a manager appointed within the firm?
} 
Starting from this categorisation, we build two dummy variables: (1) HARD_INFO, which assumes a value of 1 if the bank asks one or more of information categories (b), (d) and (e) and zero otherwise; (2) SOFT_INFO, which assumes the value of 1 if the bank uses interviews with the management on the firm's policy and prospects to assess creditworthiness of the firm (category (c)), and zero otherwise. ${ }^{4}$ In the basic analysis, we exclude the categories "brand recognition" and "other" from the definition of the two types of information, because they are not clearly described in the survey, and we exclude "collateral" because it cannot be considered to be appropriate as a screening technology. However, to the extent that brand recognition captures the firm's reputational capital, as a measure of robustness, we add category (f) to soft information (SOFT_INFO_2), while we include collateral guarantees in the definition of hard information (HARD_INFO_2).

Descriptive statistics indicate that hard information is almost universally used by lenders in their lending relationships with borrowers, as more than $90 \%$ of the companies surveyed are required to provide this type of information, either when we include or exclude collateral guarantees from the definition of hard quantitative data (HARD_INFO and HARD_INFO_2). On the contrary, the use of soft information is limited to half the surveyed firms. It can be interesting to note that the share of non-family owned and non-family managed firms transmitting SOFT INFORMATION to banks is unconditionally slightly larger than that of family owned and family managed businesses (Table 3 panel A).

In addition to the type of information, we measure the relational character of the bank-firm relationships in terms of duration: specifically, question F11 in the EFIGE survey requires firms to report the number of years the current bank has been the firm's main bank (DURATION). The average length of the lending relationships with main banks in our sample is 15 years, and it is statistically greater for family owned firms (16.8 years) than for non-family owned businesses (13.3 years). Moreover, in line with our Hypothesis 1, family firms run by family CEOs have significantly longer lasting lending relationships than those run by professional managers external to the controlling family (17.2 versus 13.9 years). As a test of robustness, we also consider a different proxy for long-lasting relationship with the bank, which derives from a

\footnotetext{
${ }^{4}$ Similar classifications are introduced by Berger and Udell, 2006; Uchida et al., 2012; Bartoli et al., 2013; Cosci et al., 2015 .
} 
survey question about the factors driving the firm's choice of the main bank. In this case, LONG_LASTING_REL is an indicator variable that takes the value 1 if the firm indicates that the key reason for the choice of the main bank is that this has a long-lasting relationship with the firm, and 0 otherwise. ${ }^{5}$ The univariate tests reported in Table 3 indicate that the share of family owned firms selecting this answer is significantly lower than that of non-family owned businesses. On the contrary, the percentage of family run firms is consistently higher than that of professionally run businesses, thus further supporting Hypothesis 1.

\subsubsection{Firms' access to credit}

In order to assess a firm's access to credit, we consider both the probability of the firm seeking credit and the likelihood of the firm experiencing a credit restriction. In particular, we rely on the following two questions of the EFIGE survey:

F13. During the last year, was the firm willing to increase its borrowing at the same interest rate of its current credit line? (i) yes; (ii) no.

F14. During the last year, did the firm apply for more credit? (i) yes, applied for it and was successful; (ii) yes, applied for it and was not successful; (iii) no, did not apply for it.

We classify firms as demanding bank credit (DEMAND = 1) if they respond (i) to the question F13, and either (i) or (ii) to question F14, and non-demanding credit (DEMAND = 0) if they respond either (ii) to the question F13 or (iii) to question F14. Then, among the firms that demand bank credit, those firms that unsuccessfully applied for it (i.e., those answering (ii) to question F14), are classified as credit restricted (RESTRICTED = 1).

\footnotetext{
${ }^{5}$ Precisely, question F12 of the EFIGE survey asks:

F12: Which factors are key in the choice of a main bank? (i) the bank offers competitive services and funding; (ii) the bank offers efficient internet services; (iii) the bank's lending criteria is clear and transparent; (iv) the bank is conveniently located; (v) the bank has an extensive international network; (vi) the bank offers also a consultancy on strategic financial decisions; (vii) the bank has a long-lasting relationship with the firm; (viii) the bank has flexible procedures/not constrained by red tape; (ix) it was the Group's main bank.
} 
Since firms desiring additional credit from banks but not applying for it (i.e., firms that respond "yes" to F13 and (iii) to F14) are arguably those that are discouraged from doing this in anticipation of a credit denial, we checked the robustness of the findings to this potential selection effect by selecting the sample firms on the basis of their willingness to borrow from banks (DESIRE, which takes the value 1 if the firm responds yes to F13 and zero otherwise). Then we use a wider definition of credit restriction, which includes potentially discouraged borrowers from among the restricted ones. Precisely, we use RESTRICTED_2 taking the value 1 if the firm responds (ii) or (iii) to F14 and zero if it responds (i).

From panel A of Table 3, 29\% of firms in our sample have a positive demand for credit, and this percentage is statistically the same regardless of the ownership and management structure. Among firms demanding loans, $30 \%$ of them experience a credit restriction. ${ }^{6}$ Unconditionally non-family owned firms, and family firms run by professional CEOs, are more likely to face credit rationing than family firms and family businesses with active family involvement, although the difference is statistically non-significant. However, when discouraged borrowers are included in the group of the restricted ones (RESTRICTED_2), family ownership significantly reduces the probability of firms experiencing credit restrictions.

\subsubsection{Control variables}

In order to correctly identify the impact of family leadership on a firm's lending relationships, and the effect of professional management on access to credit, we control for a large set of possible confounding effects. These controls also help in mitigating the omitted variable concern associated with the cross-sectional structure of our dataset.

First of all, we consider a number of standard firm-specific characteristics and balance sheet indicators. In particular, we control for: (1) the firm's age, measured by the number of years from its inception (AGE); (2) the number of workers employed in the company as proxy for the firm's size (SIZE); (3) the firm's degree of innovativeness, measured by a dummy variable that is equal to 1 for companies that invested in $\mathrm{R} \& \mathrm{D}$ in the 3 -year period covered by the survey, and zero otherwise (R\&D); (4) the company's degree of internationalisation, measured by a dummy

\footnotetext{
${ }^{6}$ Credit restricted firms are almost 4 percent of the whole sample of companies.
} 
variable equal to 1 for firms selling part of their production abroad, and zero otherwise (EXPORT); (5) the company's level of indebtedness, proxied by the debt ratio, computed as total debt over total assets (DEBT_RATIO); (6) the firm's liquidity indicator, measured as current assets over current liabilities (LIQUIDITY_RATIO); (7) the differential profitability of the company (DIFF_ROS) measured by the difference between the firm's return on sales and the median return on sales of its industry (Villalonga, 2004). As SOFT_INFO and HARD_INFO refer to the three-year period 2007-2009, all the balance sheet variables are computed as average values for the same period.

Then, we control for CEO's age, as proxy for both their experience and reputation (CEO_AGE), and gender, by a dummy that is equal to 1 for companies run by male CEOs (CEO_MALE), to take into account possible discrimination effects in access to credit for femalemanaged businesses (Bellucci et al., 2010; Alesina at al., 2013).

Finally, in order to fully account for industry- and country-specific effects, we include regional and industry dummies.

From the univariate analysis reported in panel B of Table 3, on average family owned businesses are older, smaller, less indebted, less innovative and export-oriented than non-family firms. Within family firms, the ones that keep management in the hands of family members are, on average, smaller and less innovative and export-oriented than family firms hiring professional CEOs.

\section{Empirical models}

\subsection{Relational capital and lending relationships}

According to Hypothesis 1, family firms appointing a family member as CEO are more likely to maintain soft-information-based and long-lasting lending relationships with their main bank than family firms hiring professional CEOs.

To test the first part of our hypothesis, we estimate a bivariate probit model, which takes into account the joint distribution of the two dependent variables SOFT_INFO and HARD_INFO. This choice is driven by the evidence in the banking literature that the use of hard and soft 
information are complementary in lending relationships (Uchida et al., 2006; Bartoli et al., 2013), and that more than $90 \%$ of bank relationships in our sample are characterised by the use of hard information. Specifically we test:

$$
\begin{aligned}
& \text { SOFT_INFO }=1\left[\theta_{1}+\alpha_{1} \mathrm{FAM}_{-} \mathrm{FIRM}_{\mathrm{i}}+\beta_{1} \mathrm{FAM}_{-} \mathrm{FIRM}_{\mathrm{i}} \times \mathrm{FAM} \mathrm{CEO}_{\mathrm{i}}+\mathrm{X} \gamma_{1}+\varepsilon_{1 \mathrm{i}}>0\right] \\
& \text { HARD_INFO }_{\mathrm{i}}=1\left[\theta_{2}+\alpha_{2} \mathrm{FAM}_{-} \mathrm{FIRM}_{\mathrm{i}}+\beta_{2} \mathrm{FAM}_{-} \mathrm{FIRM}_{\mathrm{i}} \times \mathrm{FAM}_{-} \mathrm{CEO}_{\mathrm{i}}+\mathrm{X} \gamma_{2}+\varepsilon_{2 \mathrm{i}}>0\right]
\end{aligned}
$$

where $X$ is a set of control variables, and $\varepsilon=\left(\varepsilon_{1}, \varepsilon_{2}\right)$ is assumed to be independent of explanatory variables with a bivariate normal distribution:

$$
\left(\begin{array}{l}
\varepsilon_{1} \\
\varepsilon_{2}
\end{array}\right) \sim N\left(\begin{array}{l}
\varepsilon_{1} \\
\varepsilon_{2}
\end{array}\right)=\left\{\left(\begin{array}{l}
0 \\
0
\end{array}\right),\left(\begin{array}{ll}
1 & \rho \\
\rho & 1
\end{array}\right)\right\}
$$

Then, turning to the second part of our Hypothesis 1, we estimate an OLS model for the duration of the lending relationship with the main bank: ${ }^{7}$

$$
\text { DURATION }_{\mathrm{i}}=\theta+\alpha \mathrm{FAM}_{-} \text {FIRM }_{\mathrm{i}}+\beta \mathrm{FAM}_{-} \text {FIRM }_{\mathrm{i}} \times \mathrm{FAM}_{-} \mathrm{CEO}_{\mathrm{i}}+\mathrm{X} \gamma+v_{\mathrm{i}}>0 \text { (3) }
$$

The differential effect that active family involvement in the company's management has on the shape of the lending relationship with the main bank is captured by the $\beta$ coefficients in Equation (3), while the effects of hiring professional managers and family ownership on lending relationships are captured by $\alpha$ and $(\alpha+\beta)$, respectively. Therefore, Hypothesis 1 is verified if $\beta_{1}$ and $\beta$ in Equations (1) and (3) are significantly greater than zero.

\subsection{Management human capital and access to bank lending}

The second step in our investigation aims to analyse whether once controlled for the information advantages of relational lending relationships, family firms with family CEOs are at a disadvantage in access to credit relative to family firms that are guided by professional executive

\footnotetext{
${ }^{7}$ As a robustness, we estimate a probit model for the probability that firm consider maintaining a long-lasting relationship the key factor in the choice of the main bank.
} 
officers. That is, we test whether banks value the leadership of professional managers, and their arguably higher management human capital, in lending decisions.

Since firms with a positive demand for credit in the period might not be randomly drawn from among the population of surveyed firms, we estimate a binary response model with sample selection (Heckman, 1979), where the selection mechanism results from firms applying for bank financing. Specifically:

$$
\begin{aligned}
& \text { RESTRICTED }_{i}=1\left[\theta_{2}+\alpha_{2} \text { FAM_FIRM }_{i}+\beta_{2} \text { FAM_FIRM }_{i} \times \text { FAM_CEO }_{i}+\delta_{2} \text { LENDING_REL }_{i}+X \gamma_{2}+v_{i}>0\right](4) \\
& \text { DEMAND }_{i}=1\left[\theta_{1}+\alpha_{1} \text { FAM_FIRM }_{i}+\beta_{1} \text { FAM_FIRM }_{i} \times \text { FAM_CEO }_{i}+\delta_{1} \text { LENDING_REL }_{i}+X \gamma_{1}+Z E+\varepsilon_{i}>0\right](5)
\end{aligned}
$$

where LENDING_RELi denotes, alternatively, one of the relational lending variables (SOFT_INFO or DURATION), $X$ is a set of exogenous covariates and $Z$ the exclusion restriction variables - cash flow over total assets (INTERNAL CAPITAL) and firm growth ( $\triangle$ SALES) which are assumed to affect the probability of demanding additional borrowing without influencing access to credit directly (Brown et al., 2011; Freel et al., 2012).

Our coefficients of interest are $\alpha_{2}$ and $\beta_{2}$, as they indicate the effect of entrusting the leadership of the family business to a family member on the probability of experiencing restrictions relative to hiring a professional CEO. Specifically, Hypothesis 2 is verified if $\beta_{2}$ is significantly larger than $\alpha_{2}$.

\section{Results}

\subsection{Hypothesis 1: Main findings}

Estimated results of the impact of family leadership on the type of relationship that they maintain with the main lenders are displayed in Table 4.

Columns 1-4 report the marginal effects of explanatory variables on the probability of a firm's creditworthiness being assessed by banks based on soft and hard information. First, note that the estimated correlation coefficients are positive and statistically significant at $1 \%$ level. This implies that the use of hard and soft information is influenced by some common 
unobservable factors and validates the choice of a bivariate model, while restricting the residuals' correlation to zero by using two distinct probit models would yield to biased and inconsistent estimates (Lollivier, 2001).

With regard to our key explanatory variables, the estimated coefficient of FAM_FIRM in columns 1 and 2 is statistically not different from zero. This indicates that family ownership does not affect the probability of firms being required to submit a particular type of information during the bank's monitoring process, and that family and non-family owned businesses have the same likelihood of creating lending relationships based on soft and hard information. However, when we distinguish between family firms managed by family CEOs and family firms hiring professional managers external to the controlling family, we find that the family leadership is associated with a heavier exchange of soft information with banks. As reported in columns 3 and 4, family firms appointing a family member as CEO are $13.2 \%$ more likely to benefit from softinformation-based lending relationships relative to family firms managed by professional CEOs, while these latter are $14.7 \%$ less likely to use soft information than non-family owned firms. By contrast, the active involvement of family members in the firm's management has no significant impact on the use of hard information.

Looking at the other firm-specific characteristics, the results in columns 1-4 show that larger companies are significantly associated with a higher probability of being required both soft and hard information. This finding is in line with the literature (Uchida et al., 2012; Bartoli et al., 2013; Ogura and Uchida, 2014), and it is not surprising if we consider that larger companies typically ask for a larger amount of credit, thus inducing banks to call for more accurate information, both hard and soft, to establish the exact business prospects and related credit risks. Consistently, we find that financially safe companies, holding a higher share of liquid assets, are less likely to be asked to provide both soft and hard information, and that companies' profitability reduces the probability of being asked for soft information. By contrast, firms engaged in exports and research and development - that is, companies investing in informationally opaque activities - are more likely to base their lending relationship on the exchange of soft information. Finally, we find that the CEO-specific characteristics, age and gender, do not significantly impact on the type of relationship built with the main bank. 
Moving on to the duration of the lending relationships with the main bank, columns 5 and 6 report estimation results of Equation (3). Family owned enterprises have, on average, longerlasting relationships with the main bank relative to non-family owned businesses. However, when family businesses are classified on the basis of their management type, we find that only family firms run by family CEOs tend to maintain long-lasting lending relationships. In particular, all else being equal, family businesses promoting family management have, on average, 2 years (or $14 \%$ ) longer lending relationships than family firms directed by professional CEOs. By contrast, for family firms hiring professional managers, the duration of the lending relationships is not statistically different from that of non-family businesses.

With regard to the other control variables, coefficient estimates indicate that the length of the bank-firm relationships significantly decreases with the size of the company, and increases with its age. Specifically, a $1 \%$ growth in the number of employees is associated with a 6-month reduction in the length of the bank-firm relationship (as the variable SIZE is expressed in logarithm), while a 1-year increase in the company's age increases the duration of the lending relationship by almost 3 months. Consistent with the idea that well-performing firms are less interested in maintaining long-lasting lending relationships, we find a negative and statistically significant coefficient for the variable DIFF_ROS. By contrast, innovative and highly indebted companies turn out to have shorter lending relationships. Finally, it is interesting to note that female CEOs are significantly associated with longer relationships with their main lender. This result is consistent with the idea of gender discrimination in the credit market (Bellucci et al., 2010; Alesina et al., 2013) to which female-run companies try to respond by maintaining close lending ties with main bank.

Summarising, and consistent with the Hypothesis 1 that the relational capital embodied in the family leadership of the company promotes the creation of soft-information-based lending relationships, our results clearly confirm that family businesses run by family CEOs are significantly more likely to maintain long-lasting relationship with their main bank based on the exchange of soft information relative to family firms managed by CEOs external to the owner family. 


\subsubsection{Hypothesis 1: Robustness tests}

As stated before, the main measures of soft and hard information used in Table 4 do not consider brand recognition and collateral from the set of information that banks can demand from their borrowers. In Table 5, we check the robustness of our results to the inclusion of these two elements. In the model reported in columns 1 and 2, SOFT_INFO_2 assumes the value 1 if the bank uses interviews with the management, and/or the recognition of the firm's brand as sources of information on the firm's merit of credit. The model in columns 3 and 4 uses HARD_INFO_2 which assumes the value 1 if the bank, besides balance sheet information, business plan and historical records of repayments, requires firms to pledge collateral. Finally, columns 5 and 6 report results for a bivariate probit model for SOFT_INFO_2 and HARD_INFO_2. The results broadly reproduce our main findings in Table 4: the marginal effect on the interaction term FAM_FIRM $\times$ FAM_CEO is positive and statistically significant, suggesting that the active involvement of family members in the company's management is associated with a $13 \%$ greater probability of transmitting soft information in the relationship with their main bank relative to family firms that are run by professional CEOs.

In column 7, we estimate a probit model on the probability of firms being required only for soft information in the bank's screening process, where ONLY_SOFT_INFO is an indicator assuming the value 1 if SOFT_INFO $=1$ and HARD_INFO $=0$, and if the value is 0 in all the other cases ${ }^{8}$. Our results further corroborate Hypothesis 1 , show that family firms conducted by a family member are $4 \%$ more likely to use soft information as the unique source of information with the main bank than family firms with professional managers. With respect to the other control variables, firm size is negatively (even if non-significantly) associated with the probability of using only soft information, while as the age of the firm increases, the probability of basing the lending relationship with main bank on private soft information also increases.

Finally, in column 8, we consider LONG_LASTING_REL as a different proxy for longlasting relationship with main banks. Once again, results are consistent with Hypothesis 1,

\footnotetext{
${ }^{8}$ In this case, the low number of observations is due to the use probit estimator. When, for robustness, we estimate a linear probability model, the number of observations raises to 5080 and our main results remain statistically significant. Results are available upon request.
} 
showing that the family CEOs have a higher propensity to consider the long-lasting relationship with the main bank a source of value for the firm relative to professional CEOs.

\subsection{Hypothesis 2: Main findings}

The second step in our investigation aims to analyse whether, once controlled for soft information availability and the duration of the lending relationship, family firms run by family members are more likely to suffer restrictions in access to bank credit as opposed to family firms conducted by professional CEOs with supposed higher management skills.

As described in Section 4.2, we apply the two-step Heckman selection procedure to eliminate the sample selection bias arising from the fact that not all firms in the sample have a positive demand for credit, and that unobservables affecting the probability of applying for credit can be correlated with unobservables affecting the likelihood of experiencing credit restriction. Therefore, we first estimate a probit model for the firm's demand for credit and then we add the inverse Mills ratio to the estimate of the likelihood of firms experiencing a credit restriction. Table 6 reports our main estimation results. ${ }^{9}$

First, it is interesting to note that exclusion restriction variables, INTERNAL_CAPITAL and $\triangle$ SALES, are both significantly and negatively correlated with the demand for bank credit. In addition, the inverse Mills ratio is negative and highly significant, suggesting that there is selfselection into the credit market: firms that participate in the credit markets are also firms that are less likely to experience credit restrictions. This means that the choice of a selection model is appropriate, and that the estimation of a simple probit model would produce downward-biased results.

Starting with the selection equation (Pr(DEMAND)), marginal effects reported in the Table indicate that family ownership does not affect the likelihood of demanding bank credit, while the direct involvement of the family in the company's management reduces this likelihood. More specifically, family firms run by family CEOs are $4.6 \%$ less likely to apply for a bank loan than

\footnotetext{
${ }^{9}$ For robustness, we also estimate a Heckman selection probit model with maximum likelihood, eliminating regional dummies in order to overcome convergence problems. In addition, we estimate a standard Heckman selection model by using a linear probability for credit restriction. Both these models provide broadly similar results, available upon request.
} 
family businesses managed by professional directors. This result runs contrary to the idea that family firms are, ceteris paribus, more likely to rely on bank credit due to their lower ability and willingness to access capital markets relative to widely held corporations. However, it supports survival and reputational theories: in order to pass a financially stable company into the hands of future generations, family managers are less likely to draw on external bank financing.

With regard to the bank relationship variables, we find that the exchange of soft information in the relationship with the main bank (SOFT_INFO and SOFT_INFO_2) significantly increases the probability of firms seeking credit. By contrast, neither DURATION nor LONG_LASTING_REL are significantly associated with credit demand.

Finally, other firm-specific characteristics significantly impact on companies' desire for additional borrowings. First, consistent with a firm's life-cycle theories, older businesses characterised by either lower market and investment opportunities or higher capacity to access other sources of external finance, result in being less likely to demand bank credit. In the same way, more profitable and liquid companies are significantly associated with the reduced likelihood of requiring additional financing. On the contrary, large, highly indebted, innovative and export-oriented firms are significantly more likely to approach banks for additional credit lines.

Moving on to our outcome equation on credit restriction, the marginal effects reported in Table 6 indicate that neither firm ownership nor management significantly affect the credit rationing status. Contrary to our Hypothesis 2, we do not find evidence supporting the idea that banks value professional leadership more than family management, as both $\beta_{2}$ and $\alpha_{2}$ coefficients are not statistically different from zero. This negative result suggests that, in credit markets, the family leadership is not associated with any significant trade-off between relational and management human capital. By contrast, the creation of soft-information-based and long-lasting lending ties results in a lower probability of being restricted in access to credit. In particular, as reported in column (2), companies required to provide soft information during the bank screening process $(\mathrm{SOFT}$ _INFO $=1)$ reduce the probability of experiencing credit restrictions by $7 \%$. This result remains statistically significant when we employ the wider definition of soft-information (SOFT_INFO_2), as specified in column (4). In this case, the likelihood of being rationed by 
banks gets reduced by more than $14 \%$ in the presence of soft-information-based lending relationships.

Similar findings are obtained for the length of the bank-firm relationship. While the coefficient for DURATION is statistically not different from zero, the negative sign for LONG_LASTING_REL indicates that the creation of long-lasting lending relationships has a beneficial effect on companies' access to credit. As reported in column (8), firms that state having long-lasting relationships with their main banks are $6.9 \%$ less likely to experience the status of credit rationed firms.

With regard to the other control variables, we find that firm size reduces the probability of experiencing credit restrictions. In addition, once controlled for the self-selection bias, innovative and export-oriented firms are less likely to be restricted in access to credit, while contrary to the hypothesis of female discrimination in credit markets, we find that when the firm's leadership is in the hands of a male, the likelihood of credit restriction is slightly higher.

Summing up, our findings on credit restriction do not support Hypothesis 2. The active involvement of family members in the management of the company has no negative influence on the firm's access to credit. By contrast, the stronger use of relational lending, more typical of family firms run by family CEOs, suggests that if there is a systematic CEO effect on family firms' access to credit, this is in favour of family CEOs. This result is consistent with D'Aurizio et al. (2015) who document the beneficial effects of private soft information and long-lasting lending relationships on credit availability to family firms during the crisis.

\subsubsection{Hypothesis 2: Robustness}

In the earlier analysis, we have considered firms that desire additional credit, but do not apply for it, as firms whose credit demand is zero. In fact, to the extent that these firms can be discouraged from applying for credit in anticipation of the high probability of experiencing rejection, it can be sensible to include them in the group of credit-restricted firms.

In order to address this concern, we check the robustness of our findings by employing a different selection equation and a larger definition of credit rationing. Specifically, we estimate the likelihood of credit restriction on the sample of firms that seek additional bank credit (that is, 
firms that respond "yes" to the question F13, or for which DESIRE = 1), considering discouraged borrowers (that is, firms that at the question F14, declare not having applied for credit although desiring it) as firms whose access to credit is restricted (RESTRICTED_2 = 1).

Estimation results reported in Table 7 broadly confirm our main findings in Table 6. Both FAM_FIRM and FAM_FIRM $\times$ FAM_CEO are not statistically significant. Hence, the higher management capital of professional CEOs does not reduce their firms' likelihood of experiencing credit restrictions in comparison with both family firms run by family managers and non-family owned companies. The provision of private soft information, and the establishment of longlasting lending relationships, instead, are confirmed to be significantly and negatively associated with the likelihood of credit restriction. In particular, firms using soft-information-based lending relationships (SOFT_INFO) are 5.4\% less likely to be restricted by banks. This percentage further increases when we adopt the extended definition of soft-information (SOFT_INFO_2): in this case, the probability of experiencing credit restrictions reduces by more than $10 \%$ (column (4)). Finally, companies having long-lasting lending relationships with their main banks are 5.9\% less likely to be credit restricted.

\section{Concluding remarks}

In this paper, we explored the impact of the trade-off between relational and management human capital on family firms' lending relationships and access to bank credit. By analysing whether the relational capital embodied in the family leadership influences the lending relationships with the main bank, we found that family firms appointing family CEOs are more likely to create softinformation-based and long-lasting lending ties. On the contrary, we did not find any significant evidence about the supposed positive effect of external CEOs on credit availability, as having family executives does not impact negatively on a firm's access to bank lending.

Overall, our results support the idea that the reputation and the social and economic relationships built over time by the family are important factors for running a firm as the creation of soft-information-based and long-lasting lending relationships reduces the likelihood of experiencing credit restrictions. However, both these elements, inherent to family firms, seem to be difficult to transfer to professional managers outside the family circle (Bennedsen and Fan, 
2014; Carillo et al., 2015). Firms run by managers external to the family show no extra advantages associated with this post-founder type of management (in our sample, externally managed firms do not have better access to credit in comparison with family managers). In order to get additional insights about this issue, an extension of our analysis would be to explore whether the founder's succession affects the transmission of relational capital on to subsequent generations and external CEOs, and whether the founders' descendants (if supposed to be less talented than their predecessor), actually differ in terms of credit availability from external managers. Despite the substantial effect of family management on the bank's preference for soft information in the credit assessment process, neither firm ownership nor management appear to play a significant role in determining the likelihood of being rationed in the credit market. As a result, the relational capital embodied in the family leadership seems to have a univocal beneficial impact on a family firm's lending relationships, as the family management favours the use of the financial information channel closest to the relational capital embedded in the family leadership. 


\section{References}

Alesina, A., Giuliano, P., Nunn, N., 2013. On the origins of gender roles: Women and the plough. The Quarterly Journal of Economics 128, 469-530.

Alfani, G., Gourdon, V., 2012. Entrepreneurs, formalization of social ties, and trustbuilding in Europe (fourteenth to twentieth centuries). Economic History Review 65, 1005-1028.

Altomonte, C., Aquilante, T., 2012. The Eu-Efige/ Bruegel-Unicredit Dataset. Bruegel Working Paper.

Amore, M. D., Bennedsen, M., 2013. The value of local political connections in a low-corruption environment. Journal of Financial Economics 110, 387-402.

Anderson, R., Reeb, D., 2003. Founding family owner and firm performance: Evidence from the S\&P500. Journal of Finance 58, 1302-1328.

Anderson, R., Mansi, S., Reeb, D., 2003. Founding family ownership and the agency cost of debt. Journal of Financial Economics 68, 263-285.

Andres, C., 2011. Family ownership, financing constraints and investment decisions. Applied Financial Economics 21, 1641-1659.

Barontini, R., Caprio, L., 2006. The Effect of Family Control on Firm Value and Performance: Evidence from Continental Europe. European Financial Management 12, 689-723.

Bartoli, F., Ferri, G., Murro, P., Rotondi, Z., 2013. SME financing and the choice of lending technology in Italy: Complementarity or substitutability? Journal of Banking \& Finance 37, 5476-5485.

Bellucci, A., Borisov, A., Zazzaro, A., 2010. Does gender matter in bank-firm relationships? Evidence from small business lending. Journal of Banking and Finance 34, 2968-2984.

Bennedsen, M., Fan, J. P. H., 2014. The Family Business Map. Assets and Roadblocks in Long Term Planning. Basingstoke, Hampshire, UK and New York, US: Palgrave Macmillan.

Bennedsen, M., Fan, J. P. H., Jian, M., Yeh, Y. 2015. The family business map: Framework, selective survey, and evidence from Chinese family firm succession. Journal of Corporate Finance 33, 212-226.

Berger, A. N., Udell, G. F., 2006. A more complete conceptual framework for SME finance. Journal of Banking and Finance 30, 2945-2966.

Bloom, N., Van Reenen, J., 2007. Measuring and explaining management practices across firms and countries. The Quarterly Journal of Economics 122, 1351-1408.

Bopaiah, C., 1998. Availability of credit to family businesses. Small Business Economics 11, 7586.

Braggion, F., 2011. Managers and (secret) social networks; the influence of the Freemasonry on firm performance. Journal of the European Economic Association 3, 1053-1081.

Brown, M., Ongena, S., Popov, A., Yesin, P., 2011. Who needs credit and who gets credit in Eastern Europe? Economic Policy 26, 93-130.

Bunkanwanicha, P., Fan, J. P. H., Wiwattanakantang, Y., 2013. The value of marriage to family firms. Journal of Financial and Quantitative Analysis 48, 611-636.

Carillo, M. R., Lombardo, V., Zazzaro, A., 2015. Family firms and entrepreneurial human capital in the process of development, CSEF Working Papers 400.

Caselli, F., Gennaioli, N., 2013. Dynastic management. Economic Inquiry 51, 971-996. 
Chelli, F., Zazzaro, A., 2008. I finanziamenti bancari allo start-up: L'esperienza e il ruolo dei direttori di filiale. In A. Zazzaro, I vincoli finanziari alla crescita delle imprese, pp. 19-44, Roma: Carocci Editore.

Chung, C., Luo, X. R., 2013. Leadership succession and firm performance in an emerging economy: successor origin, relational embeddedness, and legitimacy. Strategic Management Journal 34, 338-357.

Colli, A., 2012. Contextualizing performances of family firms: the perspective of business history. Family Business Review 25, 243-257.

Cosci, S., Meliciani, V., Sabato, V., 2015. Relationship lending and innovation: empirical evidence on a sample of European firms. Economics of Innovation and New Technology 25, 335-357.

Cucculelli, M., Peruzzi, V., 2016. Bank screening technologies and the founder effect: Evidence from European lending relationships. Finance Research Letters, http://dx.doi.org/10.1016/j.frl.2016.10.004

D’Aurizio, L., Oliviero, T., Romano, L., 2015. Family firms, soft information and bank lending in a financial crisis. Journal of Corporate Finance 33, 279-292.

Faccio, M., Lang, L. H. P., 2002. The ultimate ownership of Western European corporations. Journal of Financial Economics 65, 365-395.

Faccio, M., Parsley, D. C., 2009. Sudden deaths: taking stock of geographic ties. Journal of Financial and Quantitative Analysis 44, 683-718.

Ferri, G., Murro, P., 2015. Do firm-bank "odd couples" exacerbate credit rationing?. Journal of Financial Intermediation 24, 231-251.

Freel, M., Carter, S., Tagg, S., Mason, C., 2012. The latent demand for bank debt: characterizing "discouraged borrowers". Small Business Economics 38, 399-418.

Heckman, J., 1979. Sample selection bias as a specification error. Econometrica 47, 153-161.

La Porta, R., Lopez-De-Silanes, F., Shleifer, A., 1999. Corporate Ownership Around the World. Journal of Finance 54, 471-518.

Le Breton, I., Miller, D, 2005. Managing for the Long Run: Lessons in Competitive Advantage from Great Family Businesses, Boston MA., Harvard Business School Press.

Liberti, J. M., Mian, A. R., 2009. Estimating the effect of hierarchies on information use. Review of Financial Studies 22, 4057-4090.

Lollivier, S., 2001. Endogénéité d'une variable explicative dichotomique dans le cadre d'un modèle probit bivarié. Annales d'Economie et de Statistique 62, 251-269.

Luo, X., Kanuri, V. K., Andrews, M., 2014. How does CEO tenure matter? The mediating role of firm-employee and firm-customer relationships. Strategic Management Journal 35, 492-511.

Miller, D., Le-Breton-Miller, I., Lester, R. H., 2011. Stewardship or agency : a social embeddedness reconciliation of conduct and performance in public family businesses. Organization Science 22, 704-721.

Miller, D., Minichilli, A., Corbetta, G., 2013. Is family leadership always beneficial? Strategic Management Journal 34, 553-571.

Ogura, Y., Uchida, H., 2014. Bank consolidation and soft information acquisition in small business lending. Journal of Financial Services Research 45, 173-200.

Petersen, M. A., Rajan, R. G., 1994. The benefits of lending relationships: Evidence from small business data. Journal of Finance 49, 3-37. 
Petersen, M. A., Rajan, R. G., 1995. The effect of credit market competition on lending relationships. The Quarterly Journal of Economics 110, 407-443.

Pindado, J., de la Torre, C. 2011. Family control and investment-cash flow sensitivity: Empirical evidence from the Euro Zone. Journal of Corporate Finance 17, 1389-1409.

Presbitero, A. F., Zazzaro, A., 2011. Competition and relationship lending: Friends or foes?. Journal of Financial Intermediation 20,387-413.

Rose, M. B., 2000. Firms, networks and business values: the British and American cotton industries since 1700. Cambridge: Cambridge University Press.

Salvato, C., Melin, L., 2008. Creating value across generations in family-controlled businesses: the role of family social capital. Family Business Review 21, 259-276.

Scott, J., 2004. Small business and the value of community financial institutions. Journal of Financial Services Research 25, 207-230.

Stacchini, M., Degasperi, P., 2015. Trust, family businesses and financial intermediaries. Journal of Corporate Finance 33, 293-316.

Steijvers, T., Voordeckers, W., Vanhoof, K., 2010. Collateral, relationship lending and family firms. Small Business Economics 34, 243-259.

Stein, J. C., 2002. Information production and capital allocation: Decentralized versus hierarchical firms. Journal of Finance 57, 1891-1921.

Uchida, H., Udell, G. F., Yamori, N., 2006. SME financing and the choice of lending technology. RIETI Discussion Paper Series.

Uchida, H., Udell, G.F., Yamori, N., 2012. Loan officers and relationship lending to SMEs. Journal of Financial Intermediation 21, 97-122.

Uzzi, B., Lancaster, R., 2003. Relational embeddedness and learning: the case of bank loan managers and their clients. Management Science 49, 383-399.

Villalonga, B., 2004. Intangible resources, Tobin's q and sustainability of performance differences. Journal of Economic Behavior \& Organization 54, 205-230.

Villalonga, B., Amit, R., 2006. How do family ownership, control and management affect firm value?. Journal of Financial Economics 80, 385-441.

$\mathrm{Xu}, \mathrm{N} ., \mathrm{Xu}, \mathrm{X}, \mathrm{Yuan}, \mathrm{Q}$, , 2013. Political connections, financing friction, and corporate investment: Evidence from Chinese listed family firms. European Financial Management 19, 675-702. 


\section{Table 1}

Variable definitions and summary statistics.

\begin{tabular}{|c|c|c|c|c|}
\hline Variable & Definition & Mean & $\begin{array}{l}\text { Std. } \\
\text { Dev. }\end{array}$ & Obs. \\
\hline FAM_FIRM & $\begin{array}{l}\text { Dummy variable equal to } 1 \text { if company } \mathrm{i} \text { is directly or indirectly } \\
\text { controlled by an individual or a family owned entity, and zero } \\
\text { otherwise. } \\
\text { Source: EU-EFIGE survey }\end{array}$ & 0.70 & 0.46 & 14727 \\
\hline FAM_CEO & $\begin{array}{l}\text { Dummy variable equal to } 1 \text { if the CEO of company } i \text { is the owner of } \\
\text { the company or a member of the controlling family, and zero } \\
\text { otherwise. } \\
\text { Source: EU-EFIGE survey }\end{array}$ & 0.63 & 0.48 & 14727 \\
\hline SOFT_INFO & $\begin{array}{l}\text { Dummy variable equal to } 1 \text { if company i is required to provide soft } \\
\text { information (interviews with management on firm's policy and } \\
\text { prospects) in the screening process, and zero otherwise. } \\
\text { Source: EU-EFIGE survey }\end{array}$ & 0.56 & 0.50 & 6863 \\
\hline HARD_INFO & $\begin{array}{l}\text { Dummy variable equal to } 1 \text { if company } i \text { is required to provide hard } \\
\text { information (balance sheet information, business plan and firms' } \\
\text { targets, historical records of payments and debt service) in the } \\
\text { screening process, and zero otherwise. } \\
\text { Source: EU-EFIGE survey }\end{array}$ & 0.92 & 0.27 & 6875 \\
\hline & Length (in number of years) of the bank-firm relationship. & 15.85 & 13.81 & 6757 \\
\hline DURATION & Source: EU-EFIGE survey & & & \\
\hline SOFT_INFO_2 & $\begin{array}{l}\text { Dummy variable equal to } 1 \text { if company } i \text { is required to provide soft } \\
\text { information (interviews with management on firm's policy and } \\
\text { prospects, brand recognition) in the screening process, and zero } \\
\text { otherwise. } \\
\text { Source: EU-EFIGE survey }\end{array}$ & 0.59 & 0.49 & 6867 \\
\hline HARD_INFO_2 & $\begin{array}{l}\text { Dummy variable equal to } 1 \text { if company i is required to provide hard } \\
\text { information (balance sheet information, business plan and firms' } \\
\text { targets, historical records of payments and debt service, collateral) } \\
\text { in the screening process, and zero otherwise. } \\
\text { Source: EU-EFIGE survey }\end{array}$ & 0.96 & 0.20 & 6875 \\
\hline ONLY_SOFT_INFO & $\begin{array}{l}\text { Dummy variable equal to } 1 \text { if company } i \text { is required to provide only } \\
\text { soft information in the screening process, and zero otherwise. } \\
\text { Source: EU-EFIGE survey }\end{array}$ & 0.03 & 0.16 & 6862 \\
\hline LONG_LASTING_REL & $\begin{array}{l}\text { Dummy variable equal to } 1 \text { if company } i \text { states to have a long- } \\
\text { lasting relationship with its main bank. } \\
\text { Source: EU-EFIGE survey }\end{array}$ & 0.43 & 0.49 & 8921 \\
\hline DEMAND & $\begin{array}{l}\text { Dummy variable equal to } 1 \text { if company i desired to increase its } \\
\text { borrowing and apply for it, and zero otherwise (i.e., if the firm did } \\
\text { not desire additional borrowing or did not apply for it). } \\
\text { Source: EU-EFIGE survey }\end{array}$ & 0.29 & 0.46 & 6689 \\
\hline RESTRICTED & $\begin{array}{l}\text { Dummy variable equal to } 1 \text { if company i unsuccessfully applied for } \\
\text { credit, and zero otherwise (i.e., if the firm applied successfully for a } \\
\text { bank loan). } \\
\text { Source: EU-EFIGE survey }\end{array}$ & 0.30 & 0.46 & 1963 \\
\hline DESIRE & $\begin{array}{l}\text { Dummy variable equal to } 1 \text { if company i desired to increase its } \\
\text { borrowing, and zero otherwise. } \\
\text { Source: EU-EFIGE survey }\end{array}$ & 0.38 & 0.49 & 6693 \\
\hline
\end{tabular}




\begin{tabular}{|c|c|c|c|c|}
\hline RESTRICTED_2 & $\begin{array}{l}\text { Dummy variable equal to } 1 \text { if company i unsuccessfully applied for } \\
\text { credit or did not apply for it, and zero otherwise (i.e., if the firm } \\
\text { applied successfully for a bank loan). } \\
\text { Source: EU-EFIGE survey }\end{array}$ & 0.46 & 0.50 & 2562 \\
\hline SIZE & $\begin{array}{l}\text { Logarithm of the number of workers employed in the company. } \\
\text { Source: Bvd-Amadeus }\end{array}$ & 3.52 & 1.033 & 11442 \\
\hline AGE & $\begin{array}{l}\text { Number of years from firm's inception. } \\
\text { Source: Bvd-Amadeus }\end{array}$ & 26.50 & 22.58 & 14759 \\
\hline DEBT_RATIO & $\begin{array}{l}\text { Ratio of total debt to total assets. } \\
\text { Source: Bvd-Amadeus }\end{array}$ & 66.16 & 27.69 & 13844 \\
\hline LIQUIDITY_RATIO & $\begin{array}{l}\text { Ratio of current assets to current liabilities. } \\
\text { Source: Bvd-Amadeus }\end{array}$ & 1.54 & 1.73 & 13322 \\
\hline DIFF_ROS & $\begin{array}{l}\text { Difference between company i Return on Sales (ROS) and the } \\
\text { median ROS of its industry (at the size class and regional level). } \\
\text { Source: Bvd-Amadeus }\end{array}$ & 0.001 & 0.08 & 9827 \\
\hline $\mathrm{R} \& \mathrm{D}$ & $\begin{array}{l}\text { Dummy variable equal to } 1 \text { if company i made expenditures on } \\
\text { R\&D in the three-year period covered by the survey, and zero } \\
\text { otherwise. } \\
\text { Source: EU-EFIGE survey }\end{array}$ & 0.51 & 0.50 & 14755 \\
\hline EXPORT & $\begin{array}{l}\text { Dummy variable equal to } 1 \text { if company i sells part of its production } \\
\text { abroad, and zero otherwise. } \\
\text { Source: EU-EFIGE survey }\end{array}$ & 0.65 & 0.48 & 14734 \\
\hline INTERNAL_CAPITAL & $\begin{array}{l}\text { Ratio of cash flow to total assets. } \\
\text { Source: Bvd-Amadeus }\end{array}$ & 0.07 & 0.13 & 9776 \\
\hline$\triangle$ SALES & $\begin{array}{l}\text { Sales growth. } \\
\text { Source: Bvd-Amadeus }\end{array}$ & 0.02 & 0.21 & 9596 \\
\hline CEO_AGE & $\begin{array}{l}\text { CEO's age. } \\
\text { Source: EU-EFIGE survey }\end{array}$ & 52.46 & 10.16 & 14701 \\
\hline CEO_MALE & $\begin{array}{l}\text { Dummy variable equal to } 1 \text { if the CEO of company } i \text { is a male, and } \\
\text { zero otherwise. } \\
\text { Source: EU-EFIGE survey }\end{array}$ & 0.92 & 0.27 & 14740 \\
\hline
\end{tabular}

Source: EFIGE, European Firms in a Global Economy. 
Table 2

Distribution of the full sample by country, ownership structure and management type.

\begin{tabular}{|c|c|c|c|c|c|}
\hline \multirow[t]{2}{*}{ Country } & $\begin{array}{l}\text { All } \\
\text { firms }\end{array}$ & $\begin{array}{l}\text { Non-family } \\
\text { owned firms }\end{array}$ & $\begin{array}{l}\text { Family } \\
\text { owned firms }\end{array}$ & $\begin{array}{l}\text { Family } \\
\text { CEOs }\end{array}$ & $\begin{array}{l}\text { Non-family } \\
\text { CEOs }\end{array}$ \\
\hline & Obs. & Obs. & Obs. & Obs. & Obs. \\
\hline Austria & 443 & 83 & 360 & 316 & 44 \\
\hline France & 2976 & 1292 & 1681 & 1443 & 238 \\
\hline Germany & 2935 & 513 & 2409 & 2139 & 270 \\
\hline Hungary & 488 & 228 & 254 & 210 & 44 \\
\hline Italy & 3021 & 777 & 2244 & 2118 & 126 \\
\hline Spain & 2832 & 700 & 2132 & 1829 & 303 \\
\hline UK & 2067 & 769 & 1285 & 1119 & 166 \\
\hline Total & 14759 & 4362 & 10365 & 9174 & 1191 \\
\hline
\end{tabular}


Table 3

Descriptive statistics and univariate tests.

Panel A: Relationship lending and access to credit

\begin{tabular}{|c|c|c|c|c|c|c|c|c|c|c|c|c|c|c|}
\hline & \multicolumn{3}{|c|}{ Family firms } & \multicolumn{4}{|c|}{ Non-family firms } & \multicolumn{3}{|c|}{ Family CEOs } & \multicolumn{4}{|c|}{ Non-family CEOs } \\
\hline & Mean & St. dev. & Obs. & Mean & St. dev. & Obs. & t-statistics & Mean & St. dev. & Obs. & Mean & St. dev. & Obs. & t-statistics \\
\hline Soft info $(\%)$ & 0.55 & 0.50 & 4945 & 0.59 & 0.49 & 1908 & $-0.04 * * *$ & 0.54 & 0.50 & 4387 & 0.56 & 0.50 & 558 & -0.02 \\
\hline Hard info $(\%)$ & 0.93 & 0.26 & 4950 & 0.91 & 0.29 & 1915 & $0.02 * *$ & 0.93 & 0.26 & 4389 & 0.92 & 0.28 & 561 & 0.01 \\
\hline Soft info $2(\%)$ & 0.66 & 0.47 & 4948 & 0.71 & 0.46 & 1912 & $-0.05 * * *$ & 0.65 & 0.48 & 4389 & 0.67 & 0.47 & 559 & -0.02 \\
\hline Hard info $2(\%)$ & 0.94 & 0.24 & 4950 & 0.91 & 0.28 & 1915 & $0.03 * * *$ & 0.94 & 0.23 & 4389 & 0.92 & 0.27 & 561 & $0.02 *$ \\
\hline Duration & 16.85 & 14.42 & 4858 & 13.27 & 11.69 & 1892 & $3.58 * * *$ & 17.22 & 14.57 & 4322 & 13.91 & 12.82 & 536 & $3.31 * * *$ \\
\hline $\begin{array}{l}\text { Long-lasting_Rel } \\
(\%)\end{array}$ & 0.42 & 0.49 & 6671 & 0.46 & 0.50 & 2232 & $-0.04 * * *$ & 0.42 & 0.49 & 5914 & 0.39 & 0.49 & 757 & $0.03 *$ \\
\hline Demand (\%) & 0.30 & 0.46 & 4826 & 0.27 & 0.45 & 1857 & 0.03 & 0.30 & 0.46 & 4283 & 0.30 & 0.30 & 543 & 0.00 \\
\hline Restricted (\%) & 0.29 & 0.45 & 1458 & 0.31 & 0.46 & 505 & -0.02 & 0.29 & 0.45 & 1293 & 0.33 & 0.47 & 165 & -0.04 \\
\hline Desire $(\%)$ & 0.39 & 0.49 & 4830 & 0.37 & 0.48 & 1857 & 0.02 & 0.39 & 0.49 & 4286 & 0.39 & 0.49 & 544 & 0.00 \\
\hline Restricted $2(\%)$ & 0.45 & 0.50 & 1874 & 0.49 & 0.50 & 687 & $-0.04 * *$ & 0.44 & 0.50 & 1661 & 0.48 & 0.50 & 213 & -0.04 \\
\hline
\end{tabular}

\begin{tabular}{clll} 
Panel B: Firms' characteristics & Family CEOs & Non-family CEOs \\
\hline Family firms & Non-family firms & Mean
\end{tabular}

\begin{tabular}{|c|c|c|c|c|c|c|c|c|c|c|c|c|c|c|}
\hline & Family firm & & & Non-family & firms & & & Family CE & & & Non-family & CEOs & & \\
\hline & Mean & St. dev. & Obs. & Mean & St. dev. & Obs. & t-statistics & Mean & St. dev. & Obs. & Mean & St. dev. & Obs. & t-statistics \\
\hline Age & 27.51 & 24.22 & 10365 & 24.14 & 17.83 & 4362 & $3.37 * * *$ & 27.53 & 24.25 & 9174 & 27.35 & 24.01 & 1191 & 0.18 \\
\hline Employees & 57.46 & 114.38 & 8175 & 101.48 & 184.65 & 3721 & $-44.02 * * *$ & 50.28 & 101.15 & 7159 & 108.04 & 174.01 & 1016 & $-57.76 * * *$ \\
\hline Total assets & 7222.74 & 20588.75 & 9660 & 15601.98 & 37176.91 & 4184 & $-8379.24 * * *$ & 6055.36 & 17446.20 & 8531 & 16043.75 & 35212.97 & 1129 & $-9988.39 * * *$ \\
\hline Debt ratio & 66.61 & 27.12 & 9645 & 65.25 & 28.93 & 4170 & $1.36^{* * *}$ & 66.73 & 26.91 & 8517 & 65.74 & 28.66 & 1128 & 0.99 \\
\hline Liquidity ratio & 1.56 & 1.79 & 9236 & 1.50 & 1.58 & 4060 & $0.06^{*}$ & 1.56 & 1.77 & 8146 & 1.59 & 1.93 & 1090 & -0.03 \\
\hline Diff. ROS & 0.08 & 7.58 & 6664 & -0.17 & 7.76 & 3152 & 0.25 & 0.11 & 7.48 & 5860 & -0.14 & 8.30 & 804 & 0.25 \\
\hline R\&D (\%) & 0.50 & 0.50 & 10362 & 0.53 & 0.50 & 4361 & $-0.03 * * *$ & 0.49 & 0.50 & 9172 & 0.59 & 0.49 & 1190 & $-0.10 * * *$ \\
\hline Export (\%) & 0.64 & 0.48 & 10356 & 0.66 & 0.47 & 4346 & $-0.02 * * *$ & 0.63 & 0.48 & 9167 & 0.73 & 0.44 & 1189 & $-0.10 * * *$ \\
\hline
\end{tabular}

Notes: The table reports univariate statistics. All the variables are defined in Table 1. Accounting figures are expressed in thousands of euros. Balance sheet indicators refer to the period 2007-2009. Extreme values are recoded at the $1^{\text {st }}$ and $99^{\text {th }}$ percentiles because of outliers. Three, two and one star $(*)$ mean, respectively, 99,95 and 90 percent level of significance. 


\section{Table 4}

Hypothesis 1: Main findings.

\begin{tabular}{|c|c|c|c|c|c|c|}
\hline & Bivariate Probi & Model & Bivariate Probi & Model & OLS Model & \\
\hline & $\begin{array}{l}\text { SOFT_INFO } \\
\text { (1) }\end{array}$ & $\begin{array}{l}\text { HARD_INFO } \\
\text { (2) }\end{array}$ & $\begin{array}{l}\text { SOFT_INFO } \\
\text { (3) }\end{array}$ & $\begin{array}{l}\text { HARD_INFO } \\
\text { (4) }\end{array}$ & $\begin{array}{l}\text { DURATION } \\
\text { (5) }\end{array}$ & $\begin{array}{l}\text { DURATION } \\
\text { (6) }\end{array}$ \\
\hline$\overline{\text { FAM_FIRM }(0,1)}$ & $\begin{array}{r}-0.031 \\
{[0.045]}\end{array}$ & $\begin{array}{r}-0.026 \\
{[0.061]}\end{array}$ & $\begin{array}{r}-0.147 * \\
{[0.079]}\end{array}$ & $\begin{array}{r}-0.049 \\
{[0.107]}\end{array}$ & $\begin{array}{r}2.058 * * * \\
{[0.346]}\end{array}$ & $\begin{array}{r}0.167 \\
{[0.606]}\end{array}$ \\
\hline FAM_FIRM $\times$ FAM_CEO $(0,1)$ & & & $\begin{array}{r}0.132 * \\
{[0.074]}\end{array}$ & $\begin{array}{r}0.027 \\
{[0.102]}\end{array}$ & & $\begin{array}{r}2.171 * * * \\
{[0.593]}\end{array}$ \\
\hline SIZE & $\begin{array}{r}0.131 * * * \\
{[0.023]}\end{array}$ & $\begin{array}{r}0.091 * * * \\
{[0.034]}\end{array}$ & $\begin{array}{r}0.135^{* * * *} \\
{[0.023]}\end{array}$ & $\begin{array}{r}0.092 * * * \\
{[0.034]}\end{array}$ & $\begin{array}{r}-0.504 * * \\
{[0.206]}\end{array}$ & $\begin{array}{r}-0.428 * * \\
{[0.208]}\end{array}$ \\
\hline AGE & $\begin{array}{r}0.000 \\
{[0.001]}\end{array}$ & $\begin{array}{r}-0.003 \\
{[0.002]}\end{array}$ & $\begin{array}{r}0.000 \\
{[0.001]}\end{array}$ & $\begin{array}{r}-0.003 \\
{[0.002]}\end{array}$ & $\begin{array}{r}0.230 * * * \\
{[0.019]}\end{array}$ & $\begin{array}{r}0.231 * * * \\
{[0.019]}\end{array}$ \\
\hline DEBT_RATIO & $\begin{array}{r}-0.001 \\
{[0.001]}\end{array}$ & $\begin{array}{r}-0.001 \\
{[0.002]}\end{array}$ & $\begin{array}{r}-0.001 \\
{[0.001]}\end{array}$ & $\begin{array}{r}-0.001 \\
{[0.002]}\end{array}$ & $\begin{array}{r}-0.060 * * * \\
{[0.009]}\end{array}$ & $\begin{array}{r}-0.060 * * * \\
{[0.009]}\end{array}$ \\
\hline LIQUIDITY_RATIO & $\begin{array}{r}-0.123 * * * * \\
{[0.029]}\end{array}$ & $\begin{array}{r}-0.070 * * \\
{[0.032]}\end{array}$ & $\begin{array}{r}-0.123 * * * \\
{[0.029]}\end{array}$ & $\begin{array}{r}-0.070 * * \\
{[0.032]}\end{array}$ & $\begin{array}{r}-0.039 \\
{[0.218]}\end{array}$ & $\begin{array}{r}-0.031 \\
{[0.218]}\end{array}$ \\
\hline DIFF_ROS & $\begin{array}{c}-0.452 * \\
{[0.271]}\end{array}$ & $\begin{array}{r}-0.621 \\
{[0.406]}\end{array}$ & $\begin{array}{c}-0.465^{*} \\
{[0.272]}\end{array}$ & $\begin{array}{r}-0.624 \\
{[0.406]}\end{array}$ & $\begin{array}{r}-4.303 * * \\
{[2.160]}\end{array}$ & $\begin{array}{r}-4.506^{* *} \\
{[2.155]}\end{array}$ \\
\hline $\mathrm{R} \& \mathrm{D}(0,1)$ & $\begin{array}{r}0.225 * * * * \\
{[0.042]}\end{array}$ & $\begin{array}{r}0.065 \\
{[0.059]}\end{array}$ & $\begin{array}{r}0.227 * * * * \\
{[0.042]}\end{array}$ & $\begin{array}{r}0.065 \\
{[0.059]}\end{array}$ & $\begin{array}{r}-0.837 * * \\
{[0.345]}\end{array}$ & $\begin{array}{r}-0.808 * * \\
{[0.344]}\end{array}$ \\
\hline EXPORT $(0,1)$ & $\begin{array}{r}0.212 * * * * \\
{[0.045]}\end{array}$ & $\begin{array}{r}0.007 \\
{[0.062]}\end{array}$ & $\begin{array}{r}0.212 * * * * \\
{[0.045]}\end{array}$ & $\begin{array}{r}0.007 \\
{[0.062]}\end{array}$ & $\begin{array}{r}-0.233 \\
{[0.356]}\end{array}$ & $\begin{array}{r}-0.224 \\
{[0.356]}\end{array}$ \\
\hline CEO_AGE & $\begin{array}{r}-0.002 \\
{[0.002]}\end{array}$ & $\begin{array}{r}-0.005 \\
{[0.003]}\end{array}$ & $\begin{array}{r}-0.002 \\
{[0.002]}\end{array}$ & $\begin{array}{r}-0.005 \\
{[0.003]}\end{array}$ & $\begin{array}{r}0.114 * * * \\
{[0.017]}\end{array}$ & $\begin{array}{r}0.110 * * * \\
{[0.017]}\end{array}$ \\
\hline CEO_MALE $(0,1)$ & $\begin{array}{r}-0.021 \\
{[0.070]}\end{array}$ & $\begin{array}{r}0.064 \\
{[0.100]} \\
\end{array}$ & $\begin{array}{r}-0.015 \\
{[0.070]}\end{array}$ & $\begin{array}{r}0.066 \\
{[0.100]} \\
\end{array}$ & $\begin{array}{r}-2.043 * * * \\
{[0.598]} \\
\end{array}$ & $\begin{array}{r}-1.961 * * * \\
{[0.598]} \\
\end{array}$ \\
\hline Observations & & 5080 & & 5080 & 5005 & 5005 \\
\hline Atrho & & $0.531 * * *$ & & $0.531 * * *$ & & \\
\hline $\mathrm{R}^{2}$ & & & & & 0.19 & 0.20 \\
\hline
\end{tabular}

Notes: The table reports marginal effects in columns (1)-(4) and estimated coefficients in columns (5)-(6). Three, two and one star (*) mean, respectively, a 99, 95 and 90\% level of significance. Robust standard errors are in brackets. All the variables are defined in Table 1. Balance sheet indicators refer to the period 2007-2009. The variable SIZE is in logarithm. All regressions include industry and regional dummies, not reported for reasons of space. 
Table 5

Hypothesis 1: Robustness tests.

\begin{tabular}{|c|c|c|c|c|c|c|c|c|}
\hline & \multicolumn{2}{|c|}{ Bivariate Probit Model } & \multicolumn{2}{|c|}{ Bivariate Probit Model } & \multicolumn{2}{|c|}{ Bivariate Probit Model } & \multirow{2}{*}{$\begin{array}{l}\text { Probit Model } \\
\text { ONLY } \\
\text { SOFT_INFO } \\
\text { (7) }\end{array}$} & \multirow{2}{*}{$\begin{array}{l}\text { Probit Model } \\
\text { LONG } \\
\text { LASTING_REL } \\
(8)\end{array}$} \\
\hline & $\begin{array}{l}\text { SOFT } \\
\text { INFO_2 } \\
\text { (1) }\end{array}$ & $\begin{array}{l}\text { HARD } \\
\text { INFO } \\
(2)\end{array}$ & $\begin{array}{l}\text { SOFT } \\
\text { INFO } \\
(3)\end{array}$ & $\begin{array}{l}\text { HARD } \\
\text { INFO_2 } \\
(4)\end{array}$ & $\begin{array}{l}\text { SOFT } \\
\text { INFO_2 } \\
(5)\end{array}$ & $\begin{array}{l}\text { HARD } \\
\text { INFO_2 } \\
(6)\end{array}$ & & \\
\hline FAM_FIRM $(0,1)$ & $\begin{array}{r}-0.129 \\
{[0.080]}\end{array}$ & $\begin{array}{r}-0.043 \\
{[0.107]}\end{array}$ & $\begin{array}{l}-0.147 * \\
{[0.080]}\end{array}$ & $\begin{array}{r}-0.153 \\
{[0.129]}\end{array}$ & $\begin{array}{r}-0.128 \\
{[0.080]}\end{array}$ & $\begin{array}{r}-0.148 \\
{[0.128]}\end{array}$ & $\begin{array}{r}-0.028 \\
{[0.023]}\end{array}$ & $\begin{array}{r}-0.017 \\
{[0.024]}\end{array}$ \\
\hline FAM_FIRM $\times$ FAM_CEO $(0,1)$ & $\begin{array}{r}0.131^{*} \\
{[0.074]}\end{array}$ & $\begin{array}{r}0.013 \\
{[0.102]}\end{array}$ & $\begin{array}{r}0.134^{*} \\
{[0.074]}\end{array}$ & $\begin{array}{r}0.125 \\
{[0.127]}\end{array}$ & $\begin{array}{r}0.132 * \\
{[0.074]}\end{array}$ & $\begin{array}{r}0.110 \\
{[0.126]}\end{array}$ & $\begin{array}{r}0.040 * * \\
{[0.019]}\end{array}$ & $\begin{array}{l}0.042 * \\
{[0.023]}\end{array}$ \\
\hline SIZE & $\begin{array}{r}0.157 * * * \\
{[0.024]}\end{array}$ & $\begin{array}{r}0.089 * * * \\
{[0.034]}\end{array}$ & $\begin{array}{r}0.134 * * * \\
{[0.023]}\end{array}$ & $\begin{array}{r}-0.020 \\
{[0.042]}\end{array}$ & $\begin{array}{r}0.155^{* * * *} \\
{[0.024]}\end{array}$ & $\begin{array}{r}-0.021 \\
{[0.042]}\end{array}$ & $\begin{array}{r}-0.007 \\
{[0.006]}\end{array}$ & $\begin{array}{r}-0.006 \\
{[0.007]}\end{array}$ \\
\hline AGE & $\begin{array}{r}0.000 \\
{[0.001]}\end{array}$ & $\begin{array}{r}-0.003^{*} \\
{[0.002]}\end{array}$ & $\begin{array}{r}0.000 \\
{[0.001]}\end{array}$ & $\begin{array}{r}-0.002 \\
{[0.003]}\end{array}$ & $\begin{array}{r}0.001 \\
{[0.001]}\end{array}$ & $\begin{array}{r}-0.002 \\
{[0.003]}\end{array}$ & $\begin{array}{r}0.001 * \\
{[0.000]}\end{array}$ & $\begin{array}{r}-0.000 \\
{[0.000]}\end{array}$ \\
\hline DEBT_RATIO & $\begin{array}{r}-0.002 \\
{[0.001]}\end{array}$ & $\begin{array}{r}-0.001 \\
{[0.002]}\end{array}$ & $\begin{array}{r}-0.001 \\
{[0.001]}\end{array}$ & $\begin{array}{r}0.002 \\
{[0.002]}\end{array}$ & $\begin{array}{r}-0.002 \\
{[0.001]}\end{array}$ & $\begin{array}{r}0.002 \\
{[0.002]}\end{array}$ & $\begin{array}{r}-0.001 * * * \\
{[0.000]}\end{array}$ & $\begin{array}{r}-0.001 * * \\
{[0.000]}\end{array}$ \\
\hline LIQUIDITY_RATIO & $\begin{array}{r}-0.109 * * * \\
{[0.028]}\end{array}$ & $\begin{array}{r}-0.076 * * \\
{[0.032]}\end{array}$ & $\begin{array}{r}-0.121 * * * \\
{[0.029]}\end{array}$ & $\begin{array}{r}-0.078 * * \\
{[0.037]}\end{array}$ & $\begin{array}{r}-0.107 * * * \\
{[0.028]}\end{array}$ & $\begin{array}{r}-0.082 * * \\
{[0.037]}\end{array}$ & $\begin{array}{r}-0.014 * * \\
{[0.007]}\end{array}$ & $\begin{array}{r}-0.005 \\
{[0.007]}\end{array}$ \\
\hline DIFF_ROS & $\begin{array}{r}-0.471^{*} \\
{[0.268]}\end{array}$ & $\begin{array}{r}-0.591 \\
{[0.409]}\end{array}$ & $\begin{array}{r}-0.460^{*} \\
{[0.272]}\end{array}$ & $\begin{array}{r}-0.882^{*} \\
{[0.492]}\end{array}$ & $\begin{array}{r}-0.466^{*} \\
{[0.268]}\end{array}$ & $\begin{array}{r}-0.842 * \\
{[0.493]}\end{array}$ & $\begin{array}{r}0.008 \\
{[0.070]}\end{array}$ & $\begin{array}{r}-0.070 \\
{[0.086]}\end{array}$ \\
\hline $\mathrm{R} \& \mathrm{D}(0,1)$ & $0.245 * * *[0.042]$ & $\begin{array}{r}0.069 \\
{[0.059]}\end{array}$ & $\begin{array}{r}0.227 * * * \\
{[0.042]}\end{array}$ & $\begin{array}{r}0.115 \\
{[0.076]}\end{array}$ & $\begin{array}{r}0.245^{* * *} \\
{[0.042]}\end{array}$ & $\begin{array}{r}0.114 \\
{[0.075]}\end{array}$ & $\begin{array}{r}-0.006 \\
{[0.009]}\end{array}$ & $\begin{array}{r}0.020 \\
{[0.013]}\end{array}$ \\
\hline EXPORT $(0,1)$ & $0.198 * * *[0.045]$ & $\begin{array}{r}-0.003 \\
{[0.062]}\end{array}$ & $\begin{array}{r}0.213 * * * \\
{[0.045]}\end{array}$ & $\begin{array}{r}0.075 \\
{[0.079]}\end{array}$ & $\begin{array}{r}0.197 * * * * \\
{[0.045]}\end{array}$ & $\begin{array}{r}0.072 \\
{[0.079]}\end{array}$ & $\begin{array}{r}0.001 \\
{[0.010]}\end{array}$ & $\begin{array}{r}0.000 \\
{[0.014]}\end{array}$ \\
\hline CEO_AGE & $\begin{array}{r}-0.001 \\
{[0.002]}\end{array}$ & $\begin{array}{r}-0.005^{*} \\
{[0.003]}\end{array}$ & $\begin{array}{r}-0.002 \\
{[0.002]}\end{array}$ & $\begin{array}{r}0.000 \\
{[0.004]}\end{array}$ & $\begin{array}{r}-0.001 \\
{[0.002]}\end{array}$ & $\begin{array}{r}-0.000 \\
{[0.004]}\end{array}$ & $\begin{array}{r}-0.001 \\
{[0.001]}\end{array}$ & $\begin{array}{r}0.002 * * * * \\
{[0.001]}\end{array}$ \\
\hline CEO_MALE $(0,1)$ & $\begin{array}{r}-0.048 \\
{[0.070]}\end{array}$ & $\begin{array}{r}0.063 \\
{[0.101]}\end{array}$ & $\begin{array}{r}-0.012 \\
{[0.069]}\end{array}$ & $\begin{array}{r}0.050 \\
{[0.129]}\end{array}$ & $\begin{array}{r}-0.045 \\
{[0.070]}\end{array}$ & $\begin{array}{r}0.047 \\
{[0.128]}\end{array}$ & $\begin{array}{r}-0.005 \\
{[0.018]}\end{array}$ & $\begin{array}{r}-0.001 \\
{[0.022]}\end{array}$ \\
\hline Observations & & 5080 & & 5080 & & 5080 & 2464 & 5315 \\
\hline Atrho & & $0.554 * * *$ & & $0.452 * * *$ & & $0.508 * * *$ & & \\
\hline $\mathrm{R}^{2}$ & & & & & & & 0.17 & 0.15 \\
\hline
\end{tabular}

Notes: The table reports marginal effects. Three, two and one star $\left(^{*}\right)$ mean, respectively, a 99, 95 and $90 \%$ level of significance. Robust standard errors are in brackets. All the variables are defined in Table 1. Balance sheet indicators refer to the period 2007-2009. The variable SIZE is in logarithm. All regressions include industry and regional dummies, not reported for reasons of space. 
Table 6

Hypothesis 2: Main findings.

\begin{tabular}{|c|c|c|c|c|c|c|c|c|}
\hline \multicolumn{9}{|l|}{ Heckman Selection Probit Model: } \\
\hline & $\begin{array}{l}\text { DEMAND } \\
\text { (1) }\end{array}$ & $\begin{array}{l}\text { RESTRICTED } \\
(2)\end{array}$ & $\begin{array}{l}\text { DEMAND } \\
(3)\end{array}$ & $\begin{array}{l}\text { RESTRICTED } \\
(4)\end{array}$ & $\begin{array}{l}\text { DEMAND } \\
\text { (5) }\end{array}$ & $\begin{array}{l}\text { RESTRICTED } \\
(6)\end{array}$ & $\begin{array}{l}\text { DEMAND } \\
\text { (7) }\end{array}$ & $\begin{array}{l}\text { RESTRICTED } \\
(8)\end{array}$ \\
\hline \multirow[t]{2}{*}{ FAM_FIRM $(0,1)$} & 0.013 & -0.001 & 0.014 & -0.003 & 0.013 & -0.009 & 0.013 & -0.004 \\
\hline & {$[0.026]$} & [0.049] & {$[0.026]$} & [0.049] & [0.027] & {$[0.050]$} & {$[0.026]$} & [0.049] \\
\hline \multirow[t]{2}{*}{ FAM_FIRM×FAM_CEO $(0,1)$} & $-0.046^{*}$ & 0.003 & $-0.047 *$ & 0.004 & $-0.045^{*}$ & 0.008 & $-0.046^{*}$ & 0.006 \\
\hline & {$[0.025]$} & {$[0.051]$} & {$[0.025]$} & {$[0.051]$} & {$[0.026]$} & {$[0.052]$} & {$[0.025]$} & [0.051] \\
\hline SOFT_INFO & $\begin{array}{c}0.024 * \\
{[0.014]}\end{array}$ & $\begin{array}{r}-0.070 * * \\
{[0.030]}\end{array}$ & & & & & & \\
\hline SOFT_INFO_2 & & & $\begin{array}{r}0.055 * * * \\
{[0.014]}\end{array}$ & $\begin{array}{r}-0.144 * * * \\
{[0.038]}\end{array}$ & & & & \\
\hline DURATION & & & & & $\begin{array}{r}-0.012 \\
{[0.010]}\end{array}$ & $\begin{array}{r}0.005 \\
{[0.019]}\end{array}$ & & \\
\hline LONG_LASTING_REL & & & & & & & $\begin{array}{r}0.013 \\
{[0.014]}\end{array}$ & $\begin{array}{r}-0.069 * * \\
{[0.028]}\end{array}$ \\
\hline \multirow[t]{2}{*}{ SIZE } & $0.014 *$ & $-0.035^{* *}$ & 0.012 & $-0.030^{*}$ & $0.016^{* *}$ & $-0.039 * *$ & $0.015^{* *}$ & $-0.037 * *$ \\
\hline & [0.008] & [0.016] & [0.008] & [0.016] & [0.008] & [0.017] & [0.008] & {$[0.016]$} \\
\hline \multirow[t]{2}{*}{ AGE } & $-0.001 * *$ & 0.002 & $-0.001 * *$ & 0.002 & $-0.001 *$ & 0.001 & $-0.001 * *$ & 0.002 \\
\hline & [0.001] & {$[0.001]$} & [0.001] & {$[0.001]$} & [0.001] & {$[0.001]$} & [0.001] & [0.001] \\
\hline \multirow[t]{2}{*}{ DEBT_RATIO } & $0.003 * * *$ & $-0.003^{*}$ & $0.003^{* * * *}$ & $-0.003^{*}$ & $0.003 * * *$ & $-0.003^{*}$ & $0.003 * * *$ & $-0.003^{*}$ \\
\hline & {$[0.000]$} & {$[0.002]$} & {$[0.000]$} & {$[0.002]$} & [0.000] & {$[0.002]$} & [0.000] & {$[0.002]$} \\
\hline \multirow[t]{2}{*}{ LIQUIDITY_RATIO } & $-0.075^{* * *}$ & 0.056 & $-0.075^{* * *}$ & 0.058 & $-0.074 * * *$ & 0.046 & $-0.077 * * *$ & 0.059 \\
\hline & [0.016] & {$[0.056]$} & [0.016] & {$[0.056]$} & [0.016] & {$[0.055]$} & [0.016] & {$[0.057]$} \\
\hline \multirow[t]{2}{*}{ DIFF_ROS } & $-0.261 * *$ & 0.358 & $-0.263 * *$ & 0.370 & $-0.281 * *$ & 0.353 & $-0.265^{* *}$ & 0.359 \\
\hline & {$[0.112]$} & {$[0.248]$} & [0.111] & [0.249] & [0.115] & [0.255] & [0.112] & [0.249] \\
\hline \multirow[t]{2}{*}{$\mathrm{R} \& \mathrm{D}(0,1)$} & $0.027 *$ & $-0.100 * * *$ & $0.023 *$ & $-0.091 * * *$ & $0.028 * *$ & $-0.101 * * *$ & $0.029 * *$ & $-0.104 * * *$ \\
\hline & [0.014] & {$[0.031]$} & [0.014] & {$[0.030]$} & {$[0.014]$} & [0.031] & {$[0.014]$} & [0.031] \\
\hline \multirow{2}{*}{ EXPORT $(0,1)$} & $0.031 * *$ & $-0.079 * *$ & $0.029^{*}$ & $-0.074 * *$ & $0.031^{* *}$ & $-0.084 * *$ & $0.033^{* *}$ & $-0.084 * *$ \\
\hline & {$[0.015]$} & [0.036] & {$[0.015]$} & [0.036] & {$[0.015]$} & {$[0.036]$} & {$[0.015]$} & [0.037] \\
\hline \multirow{2}{*}{ CEO_AGE } & -0.000 & -0.002 & 0.000 & $-0.002 *$ & -0.000 & -0.002 & -0.000 & -0.002 \\
\hline & [0.001] & [0.001] & {$[0.001]$} & {$[0.001]$} & [0.001] & [0.001] & [0.001] & [0.001] \\
\hline \multirow[t]{2}{*}{ CEO_MALE $(0,1)$} & -0.016 & $0.072 *$ & -0.016 & $0.072 *$ & -0.021 & $0.078^{*}$ & -0.018 & $0.071 *$ \\
\hline & {$[0.024]$} & {$[0.042]$} & [0.024] & {$[0.042]$} & {$[0.024]$} & {$[0.042]$} & {$[0.024]$} & [0.042] \\
\hline \multirow[t]{2}{*}{ INTERNAL_CAPITAL } & $-0.268^{* *}$ & & $-0.268 * *$ & & $-0.276 * *$ & & $-0.265 * *$ & \\
\hline & {$[0.106]$} & & [0.107] & & [0.109] & & [0.107] & \\
\hline \multirow[t]{2}{*}{$\triangle$ SALES } & $-0.059 *$ & & $-0.059 *$ & & $-0.063 * *$ & & $-0.061 *$ & \\
\hline & {$[0.031]$} & & {$[0.031]$} & & [0.031] & & [0.031] & \\
\hline \multirow[t]{2}{*}{ INVERSE MILLS RATIO } & & $-0.936 * * *$ & & $-0.940 * * *$ & & $-0.913 * * *$ & & $-0.921 * * *$ \\
\hline & & [0.229] & & [0.229] & & [0.224] & & [0.228] \\
\hline Observations & 4414 & 1267 & 4414 & 1267 & 4352 & 1250 & 4415 & 1268 \\
\hline
\end{tabular}

Notes: The table reports marginal effects. Three, two and one star (*) mean, respectively, a 99, 95 and $90 \%$ level of significance. Robust standard errors are in brackets. All the variables are defined in Table 1. Balance sheet indicators refer to the period 2007-2009. The variable SIZE is in logarithm. The variable DURATION is in logarithm. All regressions include industry and regional dummies, not reported for reasons of space. 
Table 7

Hypothesis 2: Robustness tests.

\begin{tabular}{|c|c|c|c|c|c|c|c|c|}
\hline \multicolumn{9}{|l|}{ Heckman Selection Probit Model } \\
\hline & $\begin{array}{l}\text { DESIRE } \\
\text { (1) }\end{array}$ & $\begin{array}{l}\text { RESTRICTED_2 } \\
\text { (2) }\end{array}$ & $\begin{array}{l}\text { DESIRE } \\
\text { (3) }\end{array}$ & $\begin{array}{l}\text { RESTRICTED_2 } \\
\text { (4) }\end{array}$ & $\begin{array}{l}\text { DESIRE } \\
\text { (5) }\end{array}$ & $\begin{array}{l}\text { RESTRICTED_2 } \\
\text { (6) }\end{array}$ & $\begin{array}{l}\text { DESIRE } \\
\text { (7) }\end{array}$ & $\begin{array}{l}\text { RESTRICTED_2 } \\
\text { (8) }\end{array}$ \\
\hline \multirow[t]{2}{*}{$\overline{\text { FAM_FIRM }(0,1)}$} & 0.000 & 0.020 & 0.001 & 0.019 & 0.002 & 0.014 & -0.000 & 0.019 \\
\hline & {$[0.028]$} & {$[0.048]$} & [0.028] & [0.048] & {$[0.029]$} & {$[0.048]$} & {$[0.028]$} & [0.048] \\
\hline \multirow{2}{*}{ FAM_FIRM×FAM_CEO $(0,1)$} & -0.038 & -0.022 & -0.039 & -0.023 & -0.036 & -0.015 & -0.038 & -0.019 \\
\hline & [0.027] & [0.047] & [0.027] & [0.047] & {$[0.027]$} & [0.048] & {$[0.027]$} & [0.047] \\
\hline \multirow[t]{2}{*}{ SOFT_INFO } & 0.017 & $-0.054 *$ & & & & & & \\
\hline & {$[0.015]$} & {$[0.028]$} & & & & & & \\
\hline SOFT_INFO_2 & & & $\begin{array}{r}0.045 * * * \\
{[0.015]}\end{array}$ & $\begin{array}{r}-0.107 * * * * \\
{[0.032]}\end{array}$ & & & & \\
\hline \multirow[t]{2}{*}{ DURATION } & & & & & $-0.018^{*}$ & -0.003 & & \\
\hline & & & & & {$[0.010]$} & [0.019] & 0.016 & $-0.059 * *$ \\
\hline LONG_LASTING_REL & & & & & & & {$[0.015]$} & {$[0.027]$} \\
\hline \multirow[t]{2}{*}{ SIZE } & 0.008 & $-0.027 *$ & 0.006 & -0.023 & 0.010 & $-0.032 * *$ & 0.009 & $-0.030 * *$ \\
\hline & {$[0.008]$} & {$[0.015]$} & {$[0.008]$} & [0.015] & {$[0.008]$} & [0.015] & {$[0.008]$} & [0.015] \\
\hline \multirow{2}{*}{ AGE } & $-0.001 * *$ & 0.001 & $-0.001 * *$ & 0.001 & $-0.001 *$ & 0.001 & $-0.001 * *$ & 0.001 \\
\hline & [0.001] & {$[0.001]$} & [0.001] & [0.001] & [0.001] & {$[0.001]$} & [0.001] & [0.001] \\
\hline \multirow[t]{2}{*}{ DEBT_RATIO } & $0.003 * * *$ & -0.002 & $0.003 * * *$ & -0.002 & $0.003 * * *$ & -0.002 & $0.003 * * *$ & -0.002 \\
\hline & [0.000] & {$[0.002]$} & [0.000] & {$[0.002]$} & [0.001] & {$[0.002]$} & [0.000] & {$[0.002]$} \\
\hline \multirow{2}{*}{ LIQUIDITY_RATIO } & $-0.076 * * *$ & 0.050 & $-0.076 * * *$ & 0.049 & $-0.074 * * *$ & 0.044 & $-0.077 * * * *$ & 0.051 \\
\hline & [0.016] & {$[0.044]$} & [0.015] & [0.044] & [0.016] & [0.042] & [0.016] & [0.044] \\
\hline \multirow[t]{2}{*}{ DIFF_ROS } & $-0.304 * * *$ & 0.101 & $-0.305 * * *$ & 0.106 & $-0.323 * * *$ & 0.092 & $-0.307 * * *$ & 0.098 \\
\hline & [0.116] & {$[0.232]$} & [0.116] & [0.231] & [0.119] & [0.237] & {$[0.116]$} & {$[0.232]$} \\
\hline \multirow{2}{*}{$\mathrm{R} \& \mathrm{D}(0,1)$} & $0.028^{*}$ & $-0.065^{* *}$ & $0.025^{*}$ & $-0.057 * *$ & $0.028 *$ & $-0.062 * *$ & $0.029 * *$ & $-0.067 * *$ \\
\hline & {$[0.015]$} & [0.028] & [0.015] & {$[0.028]$} & {$[0.015]$} & [0.028] & {$[0.015]$} & [0.028] \\
\hline \multirow[t]{2}{*}{ EXPORT $(0,1)$} & $0.028^{*}$ & $-0.055^{*}$ & 0.026 & -0.051 & $0.028 *$ & $-0.059^{*}$ & $0.029^{*}$ & $-0.059 *$ \\
\hline & {$[0.016]$} & {$[0.032]$} & [0.016] & [0.032] & {$[0.016]$} & {$[0.032]$} & {$[0.016]$} & [0.032] \\
\hline \multirow[t]{2}{*}{ CEO_AGE } & -0.000 & -0.002 & -0.000 & -0.002 & -0.000 & -0.001 & -0.000 & -0.001 \\
\hline & {$[0.001]$} & {$[0.001]$} & [0.001] & {$[0.001]$} & {$[0.001]$} & {$[0.001]$} & {$[0.001]$} & [0.001] \\
\hline \multirow[t]{2}{*}{ CEO_MALE $(0,1)$} & -0.011 & 0.057 & -0.012 & 0.058 & -0.017 & 0.060 & -0.013 & 0.056 \\
\hline & {$[0.025]$} & {$[0.041]$} & [0.025] & [0.041] & {$[0.025]$} & [0.042] & {$[0.025]$} & [0.041] \\
\hline \multirow{2}{*}{ INTERNAL_CAPITAL } & $-0.269 * *$ & & $-0.269^{* *}$ & & $-0.279 * *$ & & $-0.267 * *$ & \\
\hline & [0.117] & & {$[0.118]$} & & {$[0.122]$} & & [0.118] & \\
\hline \multirow[t]{2}{*}{$\triangle$ SALES } & $-0.078 * *$ & & $-0.078^{* *}$ & & $-0.082 * *$ & & $-0.080 * *$ & \\
\hline & [0.033] & & {$[0.033]$} & & [0.033] & & [0.033] & \\
\hline \multirow[t]{2}{*}{ INVERSE MILLS RATIO } & & $-0.539 * * *$ & & $-0.528 * * *$ & & $-0.517 * * *$ & & $-0.524 * * *$ \\
\hline & & [0.204] & & [0.202] & & [0.198] & & [0.203] \\
\hline Observations & 4423 & 1592 & 4423 & 1592 & 4361 & 1572 & 4424 & 1593 \\
\hline
\end{tabular}

Notes: The table reports estimated coefficients. Three, two and one star (*) mean, respectively, a 99, 95 and $90 \%$ level of significance. Robust standard errors are in brackets. All the variables are defined in Table 1. Balance sheet indicators refer to the period 2007-2009. The variable SIZE is in logarithm. The variable

DURATION is in logarithm. All regressions include industry and regional dummies, not reported for reasons of space. 
